\title{
ОСОБЛИВОСТІ ДИНАМІКИ МОЛЕКУЛ СЕРЕДНЬОЇ МАСИ НА ТЛІ МОДИФІКАЦІЙ ЕКСПЕРИМЕНТАЛЬНОГО ІШЕМІЧНО- РЕПЕРФУЗІЙНОГО СИНДРОМУ КІНЦІВКИ
}

\footnotetext{
Вступ. Прогностичну роль показників ендогенної інтоксикації на тлі ішемічно-реперфузійного синдрому (IPC) кінцівки вивчено недостатньо, незважаючи на значущість цієї проблеми за умов сучасних бойових діŭ.

Мета дослідження - з'ясувати особливості зміни концентрації молекул середньої маси в сироватці крові на тлі експериментального ішемічно-реперфузійного синдрому кінцівки.

Методи дослідження. Після експериментального моделювання ішемічно-реперфузійного синдрому особливості ендогенної інтоксикації вивчали у 260 білих статевозрілих щурів-самців (віком 5-5,5 місяця), яких було поділено на групи: контрольна $(n=10)$; $Е Г 1$ - моделювання ізольованого ІРС кінцівки; ЕГ2 - моделювання ізольованої об'ємної крововтрати; ЕГЗ - поєднання ІРС кінцівки і крововтрати; ЕГ4 - моделювання ізольованої механічної травми стегна; ЕГ5 - поєднання IPC кінцівки та механічної травми. У сироватці крові після завершення експерименту визначали концентрацію молекул середньої маси (MCM). Кількісні показники обробляли статистично.

Результати й обговорення. Кожне експериментальне втручання призвело до збільшення концентрації MCM $_{254}$ і MCM $_{280}$. Особливістю є те, що в усі досліджувані періоди рівень МСМ був найвищим на тлі IPC, поєднаного з крововтратою, що свідчить про потенціювання тяжкості інтоксикації у післятравматичний період. Так, в ЕГЗ така комбінація патогенних фракторів спричинила зростання рівня МСМ $254:$ на 1-шу, 3-тю, 7-му і 14-ту доби після нанесення травми досліджуваний показник перевищив дані контрольної групи в 3,7, 4,2, 3,2 та 2,8 раза відповідно, тоді як концентрація МСм 280 через 1 год після втручання була більшою, ніж у контрольній групі, на 53,5 \%. На 1-шу, 3-тю, 7-му і 14-ту доби показник був ще вищим -у 3,4, 4, 3,4 та 3 рази відповідно.

Висновки. Кожне з експериментальних втручань призвело до порушення детоксикаційно-видільної фрункції організму, що проявилося зростанням концентрації молекул середньої маси. При цьому застосування кровоспинного джгута, яке від самого початку повинно проявляти лікуваний ефект, імовірно, мало і патогенний вплив, що необхідно враховувати при проведенні лікувальних дій таким постраждалим.
}

КЛЮЧОВІ СЛОВА: молекули середньої маси; ендогенна інтоксикація; ішемія-реперфузія; травма; крововтрата; експеримент.

ВСТУП. Ендогенна інтоксикація призводить до суттєвих змін у біологічних мембранах, що, у свою чергу, визначає особливості лікувальної тактики [1]. Зміни на тлі ішемічно-реперсузійного синдрому (IPC) характеризуються такими патогенетичними явищами: вже в перші хвилини після реперфузії $€$ велика ймовірність клітинного ушкодження включно до їх загибелі через активацію механізмів посиленого входу іонів $\mathrm{Ca}^{2+}$, зміни міхондріальної проникності, ушкодження мембран і цитоскелета (індукувані зростанням активності протеаз), що здатні навіть поодинці критично вплинути на тканини [2]. Не остання роль належить і надмірній концентрації активних фрорм кисню [3]. Усе це в комплексі 3 (с) Н. В. Волотовська, 2020. активацією прозапальних цитокінів на тлі гіпоксії тканин, напруження антиоксидантної системи [4], неадекватної роботи екскреторної фрункції внутрішніх органів порушує коректну регуляцію гомеостазу i, таким чином, ускладнює перебіг первинного захворювання [5]. Про неоднозначну і здебільшого токсичну роль молекул середньої маси (МСM), зокрема з точки зору навантаження на органи виділення, сказано в багатьох джерелах [6-11].

Виявлення концентрації молекул середньої маси $€$ одним з найбільш доступних та простих способів оцінити ступінь ураження організму як результат ендогенної інтоксикації [12], оскільки серед комплексу цих низько- та середньомолекулярних речовин є і такі, що пригнічують клітинний 
імунітет, неспецифічну реактивність, інгібують окремі біологічно активні речовини організму.

На зростання концентрації МСМ впливає інтенсивність розпаду біологічних субстратів, що на тлі зниження екскреторної функції гепаторенального комплексу виявляє ступінь порушення фрункціонування організму в цілому [13].

Мета дослідження - з'ясувати особливості зміни концентрації молекул середньої маси в сироватці крові на тлі експериментального ішемічно-реперфузійного синдрому кінцівки.

МЕТОДИ ДОСЛІДЖЕННЯ. ДослідЖували ендогенну інтоксикацію в сироватці крові за умов впливу стресових чинників та їх поєднання.

Експеримент виконано на 260 білих нелінійних щурах-самцях (віком 5-5,5 місяця), яких утримували в традиційних умовах віварію. Для досягнення мети було сформовано контрольну (КГ) і 5 дослідних груп: ЕГ1 - накладання кровоспинного джгута на стегно протягом 2 год (ізольований IPC кінцівки); ЕГ2 - моделювання крововтрати; ЕГЗ - поєднання IPC кінцівки і крововтрати; ЕГ4 - нанесення на стегнову кістку механічної травми $з$ метою моделювання перелому за допомогою апарата щП-1; ЕГ5 - поєднання IPC кінцівки та механічної травми.

Експеримент проведено за умов тіопенталнатрієвого знеболювання (40 мг/кг) з дотриманням загальних правил і положень Європейської конвенції про захист хребетних тварин, що використовуються для дослідних та інших наукових цілей (Страсбург, 1986), Резолюції Першого національного конгресу з біоетики (Київ, 2011) та Закону Міністерства здоров'я України від 23 вересня 2009 р. № 690 [14]. Так, ішемічнореперфузійний синдром моделювали, наклавши на верхню $1 / 3$ стегна смужку гумового джгута шириною $1 \mathrm{~cm}$, розраховуючи силу натиску під контролем маркування, нанесеного на джгут. Залишали на 2 год, після чого тварину звільняли. Для моделювання крововтрати здійснювали забір крові зі стегнової вени в об'ємі 40 \% від об'єму циркулюючої крові. Тварин виводили 3 експерименту через 1 год після декомпресії чи інших втручань, на 1-шу, 3-тю, 7-му і 14-ту доби після нанесення травми шляхом тотальної кровотечі із серця.

Вміст середньомолекулярних пептидів визначали шляхом виділення їх кислоторозчинної фрракції 3 наступною детекцією десятикратно розведеної надосадової рідини при довжинах хвиль 254 та 280 нм $[15,16]$. Отриманий цисрровий матеріал було оброблено методом варіаційної статистики 3 використанням t-критерію Стюдента. Розраховували середні арисрметичні величини (М), похибки середніх арифметич- них (m), коефіцієнти варіації, а також середні квадратичні відхилення. Зміни вважали достовірними при $p \leq 0,05$. У таблицях рівень значимості вказано тільки для достовірних результатів. Відмінності між середніми величинами вважали достовірними за вірогідності альтернативної гіпотези не менше ніж 0,95 [17].

Для розрахунків використовували комп'ютерну програму Microsoft Excel XP (США). Усі отримані результати було оброблено методом варіаційної статистики.

РЕЗУЛЬТАТИ Й ОБГОВОРЕННЯ. ДовеДеНО, що спричинити ендотоксикоз може циркуляторна чи тканинна гіпоксія, зокрема підтверджено роль МСМ, які були проказником тяжкості розладів, що виникають у водолазів [18].

Як видно 3 таблиці 1, моделювання навіть ізольованої ішемії-реперфузії призвело до суттєвої зміни концентрації середньомолекулярних сполук порівняно з рівнем контрольних значень. Так, уже через 1 год після втручання в ЕГ1 показник статистично достовірно перевищив дані КГ на 44,0 \%, у ЕГ2 - на 64,8 \%, на тлі IPC, поєднаного 3 крововтратою (ЕГЗ), - на 48,8 \%, а також у ЕГ 4 - на 26,4 \%, в ЕГ5 - на 32,0 \% порівняно з КГ. У наступні періоди динаміка змін була такою: на тлі ізольованого IPC в ЕГ1 показник був більшим від даних КГ на 55,2, 76,8 та 42,4 \% на 1-шу, 3-тю і 7-му доби відповідно. На 14-ту добу він усе ще залишався підвищеним, порівняно 3 КГ, на 7,2 \%, хоча достовірність відмінності становила р >0,05. На тлі ізольованої крововтрати концентрація $\mathrm{MCM}_{254}$ зросла значно більше і на 1-шу, 3-тю, 7-му і 14-ту доби перевищила рівень КГ, відповідно, у 2,8, 3,2, 2,4 раза та на 79,2 \%. При цьому поєднання IPC і крововтрати в ЕГЗ призвело до ще більшого зростання концентрації МСМ: на 1-шу, 3-тю, 7-му і 14-ту доби після нанесення травми показник перевищив дані КГ у 3,7, 4,2, 3,2 та 2,8 раза. Що стосується динаміки в ЕГ 4, то на 1-шу, 3-тю, 7-му і 14-ту доби вміст МСМ був більшим від даних КГ на 62,4, $88,0,84,0$ та 20,0 \%, тоді як в ЕГ5 цей рівень був більш вираженим і перевищив дані КГ на 1-шу, 3-тю, 7-му і 14-ту доби на 98,4 \%, у 2,5 раза, на 95,2 та 60,8 \% відповідно.

Незалежно від тяжкості втручання динаміка досліджуваного показника мала певні закономірності-концентрація МСМ зростала до 3-ї доби, після чого рівень знижувався, хоча і не повертався до норми.

Так, в ЕГ1 на 1-шу добу показник перевищив статистично достовірно дані 1 год на 7,7 \%, на 3-тю - був більшим від рівня 1 год і 1-ї доби на 22,7 та 13,9 \%, на 7-му - нижчим від рівня 3-ї доби на 19,5 \%, а на 14-ту - меншим від 
Таблиця 1 - Вміст МСM $_{254}$ у сироватці крові після ішемії-реперфузії кінцівки, крововтрати і скелетної травми (Me (LQ; UQ)) - медіана (нижній та верхній квартилі)

\begin{tabular}{|c|c|c|c|c|c|}
\hline \multirow{2}{*}{ Дослідна група } & \multicolumn{5}{|c|}{ Термін реперфузійного періоду } \\
\hline & 1 год & 1-ша доба & 3-тя доба & 7-ма доба & 14-та доба \\
\hline \multicolumn{6}{|c|}{ Контроль $=0,125(0,123 ; 0,134)(n=10)$} \\
\hline$E \Gamma 1$ & $0,180^{*}$ & $0,194^{*}$ & $0,221^{*}$ & $0,178^{*}$ & 0,134 \\
\hline Ішеміч & $(0,173 ; 0,184)$ & $(0,189 ; 0,197)$ & $(0,207 ; 0,235)$ & $(0,156 ; 0,191)$ & $(0,128 ; 0,137)$ \\
\hline синдро & $(n=10)$ & $(n=10)$ & $(n=10)$ & $(n=10)$ & $(n=10)$ \\
\hline EГ2 & $0,206^{*}$ & $0,354^{*}$ & $0,404^{*}$ & $0,301^{*}$ & $0,224^{*}$ \\
\hline Кровов & $\begin{array}{c}(0,189 ; 0,211) \\
(n=7)\end{array}$ & $\begin{array}{c}(0,329 ; 0,366) \\
(n=7)\end{array}$ & $\begin{array}{c}(0,391 ; 0,428) \\
(n=6)\end{array}$ & $\begin{array}{c}(0,295 ; 0,316) \\
(n=7)\end{array}$ & $\begin{array}{c}(0,213 ; 0,256) \\
(n=7)\end{array}$ \\
\hline EГЗ & $0,186^{*}$ & $0,458^{*}$ & $0,531^{*}$ & $0,411^{*}$ & $0,352^{*}$ \\
\hline Ішемі & $(0,180 ; 0,194)$ & $(0,437 ; 0,490)$ & $(0,522 ; 0,555)$ & $(0,388 ; 0,421)$ & $(0,343 ; 0,370)$ \\
\hline синдр & $(n=6)$ & $(n=6)$ & $(n=6)$ & $(n=6)$ & $(n=5)$ \\
\hline $\mathrm{p}_{1-3}$ & $>0,05$ & $<0,05$ & $<0,05$ & $<0,05$ & $<0,05$ \\
\hline$p_{2-3}$ & $>0,05$ & $<0,05$ & $<0,05$ & $<0,05$ & $<0,05$ \\
\hline$E \Gamma 4$ & $0,158^{\star}$ & $0,203^{*}$ & $0,235^{*}$ & $0,230^{*}$ & $0,152^{*}$ \\
\hline Травма & $\begin{array}{c}(0,144 ; 0,162) \\
(n=10)\end{array}$ & $\begin{array}{c}(0,200 ; 0,205) \\
(n=10)\end{array}$ & $\begin{array}{c}(0,216 ; 0,259) \\
(n=10)\end{array}$ & $\begin{array}{c}(0,216 ; 0,235) \\
(n=10)\end{array}$ & $\begin{array}{c}(0,141 ; 0,162) \\
(n=10)\end{array}$ \\
\hline EГ5 & $0,165^{*}$ & $0,248^{*}$ & $0,314^{*}$ & $0,244^{*}$ & $0,201^{*}$ \\
\hline Ішеміч & $(0,150 ; 0,173)$ & $(0,225 ; 0,261)$ & $(0,300 ; 0,345)$ & $(0,232 ; 0,253)$ & $(0,192 ; 0,224)$ \\
\hline синдром+травма & $(n=9)$ & $(n=9)$ & $(n=8)$ & $(n=9)$ & $(n=9)$ \\
\hline$p_{1-5}$ & $>0,05$ & $<0,05$ & $<0,05$ & $<0,05$ & $<0,05$ \\
\hline $\begin{array}{l}p_{4-5} \\
\end{array}$ & $>0,05$ & $<0,05$ & $<0,05$ & $>0,05$ & $<0,05$ \\
\hline
\end{tabular}

Примітки. Тут і в таблиці 2:

1.* - відмінності стосовно контрольної групи статистично достовірні $(p<0,05)$.

2. $p_{1-3}-$ достовірність відмінностей стосовно ЕГ1 і ЕГЗ.

3. $\mathrm{p}_{2-3}$ - достовірність відмінностей стосовно ЕГ2 і ЕГЗ.

4. $\mathrm{p}_{1-5}-$ достовірність відмінностей стосовно ЕГ1 і ЕГ5.

5. $\mathrm{p}_{4-5}-$ достовірність відмінностей стосовно ЕГ4 і ЕГ5.

рівня 1 год, 1-ї, 3-ї, 7-ї і 14-ї діб на 25,6, 30,9, 39,4 та 24,7 \% відповідно. В ЕГ2 коливання показника були не такими плавними, як в ЕГ1: на 1-шу добу він перевищив дані 1 год на 71,8 \%, на 3-тю - був більшим від рівня 1 год і 1-ї доби на 96,1 та 14,1\%, на 7-му - хоч і перевищив дані 1 год на 46,1 \%, проте знизився, порівняно 3 рівнем 1-ї і 3-ї діб, на 15,0 та 25,5 \% відповідно. Що стосується 14-ї доби, то показник був меншим, порівняно з 1-ю, 3-ю і 7-ю добами, на 36,7, 44,6 та 25,6 \% відповідно. В ЕГЗ на 1-шу добу показник перевищив дані 1 год у 2,5 раза, на 3-тю - був більшим від рівня 1 год і 1-ї доби у 2,9 раза та на 15,9 \%, на 7-му - вищим від даних 1 год на 10,3 \%, щодо 3-ї доби - на 22,6 \%, на 14-ту - більшим від даних 1 год на 89,2 \%, відносно 1-ї доби - на 23,1 \%, 3-ї доби - на 33,7 \%, 7-ї доби - на 14,3 \%. В ЕГ4 на 1-шу добу показник був більшим від даних 1 год на 28,5 \%, на 3-тю добу щодо 1 год і 1-ї доби - на 48,7 та 15,8 \% відповідно, на 7-му - перевищив рівень 1 год і 1-ї доби на 45,6 та 13,3 \%, а на 14-ту - виявився нижчим від даних 1-ї, 3-ї і 7-ї діб на 25,1, 35,3 та 33,9 \% відповідно. В ЕГ5 на 1-шу добу показник був більшим від даних 1 год на 50,3 \%, на 3-тю перевищив рівень 1 год і 1-ї доби на 90,3 та 26,6 \%, на 7-му - був більшим від даних 1 год на
47,9\%, але зменшився відносно 3-ї доби на 22,3 \%, на 14-ту - був вищим від рівня 1 год на 36,0 \% і знизився щодо 3-ї і 7-ї діб на 36,0 та 17,6 \% відповідно.

При аналізі змін величини досліджуваного показника у сироватці крові експериментальних тварин, які належали до різних груп, встановлено такі відмінності. Так, на 1-шу добу після втручання показник MCM $_{254}$ в ЕГЗ був статистично достовірно більшим від рівня ЕГ1 у 2,4 раза, щодо ЕГ2 - на 29,4 \%. На 3-тю добу показник ЕГЗ перевищив дані ЕГ1 і ЕГ2 у 2,4 раза та на 31,4 \%, на 7-му - був більшим від рівня ЕГ1 і ЕГ2 у 2,3 раза та на $36,5 \%$, тоді як на 14-ту - залишався вищим від даних ЕГ1 і ЕГ2 у 2,6 раза та на 57,1\%. Що стосується ЕГ5, то показник був більшим від рівня ЕГ1 і ЕГ4 на 27,8 та 22,2 \% відповідно, тоді як на 3-тю добу перевищив дані цих груп на 42,1 і 33,6 \%. На 7-му добу показник ЕГ1 був більшим лише від рівня ЕГ1 - на 37,1 \%. На 14-ту добу перевищив дані ЕГ1 і ЕГ4 на 50,5 та 32,2 \% відповідно.

Як видно з таблиці 2, динаміка зростання концентрації $\mathrm{MCM}_{280}$ порівняно 3 контрольною групою мала свої особливості - досягнення піка на 3-тю добу в ЕГ1, ЕГ2, ЕГЗ і на 7-му добу в ЕГ4 та ЕГ5. Таким чином, на тлі ізольованого засто- 
Таблиця 2 - Вміст MCM 280 після ішемії-реперфузії кінцівки і крововтрати (Me (LQ; UQ)) медіана (нижній та верхній квартилі)

\begin{tabular}{|c|c|c|c|c|c|}
\hline \multirow{2}{*}{ Дослідна група } & \multicolumn{5}{|c|}{ Термін реперфузійного періоду } \\
\hline & 1 год & 1-ша доба & 3-тя доба & 7-ма доба & 14-та доба \\
\hline \multicolumn{6}{|c|}{ Контроль $=0,114(0,105 ; 0,120)(n=10)$} \\
\hline$E \Gamma 1$ & $0,134^{*}$ & $0,195^{\star}$ & $0,193^{*}$ & $0,159^{\star}$ & 0,119 \\
\hline Ішемічно-реперсрузійний & $(0,127 ; 0,137)$ & $(0,184 ; 0,212)$ & $(0,190 ; 0,208)$ & $(0,145 ; 0,168)$ & $(0,102 ; 0,132)$ \\
\hline синдром & $(n=10)$ & $(n=10)$ & $(n=10)$ & $(n=10)$ & $(n=10)$ \\
\hline EГ2 & $0,169^{*}$ & $0,233^{*}$ & $0,383^{*}$ & $0,290^{*}$ & $0,316^{*}$ \\
\hline Крововтрата & $\begin{array}{c}(0,156 ; 0,181) \\
(n=7)\end{array}$ & $\begin{array}{c}(0,220 ; 0,239) \\
(n=7)\end{array}$ & $\begin{array}{c}(0,372 ; 0,395) \\
(n=6)\end{array}$ & $\begin{array}{c}(0,268 ; 0,315) \\
(n=7)\end{array}$ & $\begin{array}{c}0,309 ; 0,357) \\
(n=7)\end{array}$ \\
\hline ЕГЗ & $0,175^{\star}$ & $0,391^{*}$ & $0,461^{*}$ & $0,390^{\star}$ & $0,341^{*}$ \\
\hline Ішемічно-реперфуузійний & $(0,171 ; 0,187)$ & $(0,361 ; 0,406)$ & $(0,426 ; 0,485)$ & $(0,353 ; 0,435)$ & $(0,339 ; 0,395)$ \\
\hline синдром+крововтрата & $(n=6)$ & $(n=6)$ & $(n=6)$ & $(n=6)$ & $(n=5)$ \\
\hline$p_{1-3}$ & $<0,05$ & $<0,05$ & $<0,05$ & $<0,05$ & $<0,05$ \\
\hline $\mathrm{p}_{2-3}$ & $<0,05$ & $<0,05$ & $<0,05$ & $<0,05$ & $<0,05$ \\
\hline$E \Gamma 4$ & $0,171^{*}$ & $0,209^{*}$ & $0,248^{*}$ & $0,254^{*}$ & $0,232^{*}$ \\
\hline Травма & $\begin{array}{c}(0,158 ; 0,175) \\
(n=10)\end{array}$ & $\begin{array}{c}(0,201 ; 0,223) \\
(n=10)\end{array}$ & $\begin{array}{c}(0,234 ; 0,254) \\
(n=10)\end{array}$ & $\begin{array}{c}(0,245 ; 0,270) \\
(n=10)\end{array}$ & $\begin{array}{c}(0,211 ; 0,240) \\
(n=10)\end{array}$ \\
\hline EГ5 & $0,168^{\star}$ & $0,245^{\star}$ & $0,326^{*}$ & $0,298^{*}$ & 0,276 \\
\hline Ішемічно-реперсрузійний & $(0,157 ; 0,173)$ & $(0,234 ; 0,268)$ & $(0,312 ; 0,345)$ & $(0,286 ; 0,310)$ & $(0,251 ; 0,288)$ \\
\hline синдром+травма & $(n=9)$ & $(n=9)$ & $(n=8)$ & $(n=9)$ & $(n=9)$ \\
\hline$p_{1-5}$ & $<0,05$ & $<0,05$ & $<0,05$ & $<0,05$ & $<0,05$ \\
\hline $\begin{array}{l}1-5 \\
p_{4-5}\end{array}$ & $>0,05$ & $<0,05$ & $<0,05$ & $<0,05$ & $<0,05$ \\
\hline
\end{tabular}

сування джгута в ЕГ1 досліджуваний показник перевищив дані КГ через 1 год на 17,5 \%, на 1-шу і 3-тю доби - був більшим від рівня КГ на 71,1 та 69,3 \% відповідно. Також залишався збільшеним і на 7-му добу - на 39,5 \%, а на 14-ту добу він перевищив дані КГ на 4,4 \%.

На тлі ізольованої крововтрати в ЕГ2 показник $\mathrm{MCM}_{280}$ через 1 год після втручання був більшим від даних КГ на 48,2 \%. Різке зростання зафріксовано на 1-шу, 3-тю і 7-му доби після нанесення травми, коли показник перевищив рівень КГ у 2, 3,4 та 2,5 раза відповідно. На 14-ту добу він теж значно перевищив дані КГ - у 2,8 раза. На тлі крововтрати, поєднаної із застосуванням джгута, в ЕГЗ через 1 год після втручання показник був більшим від даних КГ на 53,5 \%. На 1-шу, 3-тю, 7-му і 14-ту доби він суттєво підвищився - в 3,4, 4, 3,4 та 3 рази відповідно.

На тлі ізольованої травми в ЕГ4 показник через 1 год після втручання був більшим від рівня КГ на $50 \%$, тоді як на 1-шу добу - підвищився на 83,3 \% порівняно з КГ. На 3-тю і 7-му доби після нанесення травми він був більшим від даних КГ у 2,2 раза. На 14-ту добу знижувався, проте і далі перевищував рівень КГ у 2 рази. Що стосується концентрації $\mathrm{MCM}_{280}$ в ЕГ5, в якій травма поєднувалась з IPC, то вже через 1 год після втручання показник був більшим від даних КГ на 47,4 \%, на 1-шу, 3-тю і 7-му доби - перевищив вихідний рівень у 2,1, 2,9 та 2,6 раза. Також на 14-ту добу залишався суттєво збільшеним порівняно з КГ - у 2,4 раза.
Що стосується вираження величини досліджуваного показника в кожній окремій групі, то динаміка концентрації MCM $_{280}$ була схожою до $\mathrm{MCM}_{254}$. Так, уже через 1 год показник ЕГЗ був статистично достовірно більшим від даних ЕГ1 і ЕГЗ на 30,6 та 3,0 \%. На 1-шу добу показник ЕГЗ перевищив рівень ЕГ1 і ЕГ2 у 2 рази та на $67,8 \%$, а на 3-тю - був більшим від даних 1-ї доби у 2,4 раза і на 20,4 \%. На 7-му добу на тлі загального зниження вмісту показник і далі залишався вищим від рівня ЕГ1 та ЕГ2 у 2,5 раза і на 34,5\%, а на 14-ту - був більшим у 2,9 раза та на 7,9 \% відповідно. Що стосується ЕГ5, то через 1 год після втручання показник перевищив дані ЕГ1 на 25,4 \%, на 1-шу добу - був більшим від рівня ЕГ1 і ЕГ4 на 25,6 та 17,2 \%, на 3-тю перевищив дані груп порівняння на 68,9 і 31,5 \%, тоді як на 7-му - був більшим від даних відповідних груп на 87,4 та 17,3 \%. На 14-ту добу показник і далі залишався підвищеним порівняно 3 ЕГ1 і ЕГ4 - у 2,3 раза та на 19,0 \%.

Також інші вчені встановили, що зростання концентрації МСМ у пацієнтів із нирковою недостатністю $є$ прогностично несприятливим проявом, навіть на тлі нормалізації показників креатиніну та сечовини [19]. Загалом такі особливості динаміки досліджуваних показників узгоджуються з даними, наведеними в цій публікації та отриманими раніше, - вони свідчать про розвиток гепаторенального синдрому в критичний період посттравматичної хвороби [20]. Дисорункція життєво важливих органів лежить в основі порушення елімінації патологічних метаболітів із 
плазми крові, а оскільки динаміку концентрації даних речовин контролюють кілька органів - детоксикації та виділення, то в цьому полягає пояснення певної неоднорідності у складі різних фрракцій МСМ [21], що підтверджено в даному експерименті.

ВИСНОВКИ. Застосування ефективного кровоспинного засобу - джгута, яке має на меті врятувати життя постраждалого, на жаль, при поєднанні кількох несприятивих чинників здатне ускладнювати перебіг основного захворювання через розвиток ішемічно-реперфузійного синдрому. В даному експерименті доведено статистично достовірне збільшення нагромадження молекул середньої маси на тлі ішемічно-репер- фрузійного синдрому, поєднаного з крововтратою, - і воно було найбільш виражене порівняно з ізольованим ішемічно-реперфузійним синдромом чи ізольованою крововтратою, а також на тлі ішемічно-реперфузійного синдрому, поєднаного 3 механічною травмою стегнової кістки, порівняно з ізольованим ішемічно-реперфузійним синдромом або ізольованою травмою.

Перспективи подальших досліджень. Всебічне висвітлення змін, що виникають на тлі ішемічно-реперфузійного синдрому кінцівки, сприятиме глибшому розумінню патогенетичних ланок післяреперфузійних змін і в перпективі дасть змогу розробляти методи для зменшення негативних наслідків такого способу лікування.

\section{СПИСОК ЛІТЕРАТУРИ}

1. Значение мембраностабилизирующей способности антиоксидантов в их детоксикационном эффекте [Электронный ресурс] / С. Г. Анаскин, Т. И. Власова, Г. А. Шевалаев [и др.] // Современные проблемы науки и образования. - 2012. - № 6. - Режим доступа : http://www.science-education.ru/ru/article/view?id=7372.

2. Ruiz-Meana M. Pathophysiology of ischemiareperfusion injury: New therapeutic options for acute myocardial infarction / M. Ruiz-Meana, D. García-Dorado // Revista espanola de cardiologia. - 2009. No. 62 (2). - P. 199-209.

3. Current mechanistic concepts in ischemia and reperfusion injury / M. Y. Wu, G. T. Yiang, W. T. Liao [et al.] // Cellular Physiology and Biochemistry. - 2018. No. 46. - P. 1650- 1667. DOI: 10.1159/000489241. Cellular Physiology and Biochemistry.

4. Volotovska N. V. Changes in the glutathione system's activity of internal organs in the first hours of experimental limb ischemia-reperfusion syndrome, combined with blood loss and mechanical injury $I$ N. V. Volotovska, T. Nhokwara Cliff, I. V. Zhulkevych // Здобутки клінічної і експериментальної медицини. 2019. - № 1. - P. 17-23.

5. Ore A. Oxidative stress and antioxidant biomarkers in clinical and experimental models of non-alcoholic fatty liver disease / A. Ore, O. A. Akinloye // Medicina. 2019. -No.55(2). -P. 26. DOI:10.3390/medicina55020026

6. Middle-molecule uremic toxins: A renewed interest / Y. Nlandu, M. Padden, A. Seidowsky [et al.] // Nephrologie \& Therapeutique. - 2019. - No. 15 (2). - P. 82-90. DOI: 10.1016/j.nephro.2018.09.003

7. Monitoring treatment of acute kidney injury with damage biomarkers / T. J. Pianta, L. Succar, T. Davidson [et al.] // Toxicology Letters. - 2017. - No. 268. - P. 63-70. DOI: 10.1016/j.toxlet.2017.01.001.

8. Wasung M. E. Biomarkers of renal function, which and when? / M. E. Wasung, L. S. Chawla, M. Madero // Clinica Chimica Acta. - 2015. - No. 438. - P. 350-357. DOI:10.1016/j.cca.2014.08.039.
9. Assessment of biochemical markers in the early post-burn period for predicting acute kidney injury and mortality in patients with major burn injury: comparison of serum creatinine, serum cystatin- $\mathrm{C}$, plasma and urine neutrophil gelatinase-associated lipocalin / H. T. Yang, H. Yim, Y. S. Cho [et al.] // Critical Care. - 2014. No. 18 (4). R151 - 12 p. DOI:10.1186/cc13989.

10. Waring W. S. Earlier recognition of nephrotoxicity using novel biomarkers of acute kidney injury I W. S. Waring, A. Moonie // Clinical Toxycology Testing. 2011. - No. 49 (8). - P. 720-728. DOI:10.3109/155636 50.2011.615319.

11. The peptidic middle molecules: is molecular weight doing the trick? / M. Chmielewski, G. Cohen, A. Wiecek, J. C. Jesús // Seminars in Nephrology. 2014. - No. 34 (2). - P. 118-134. DOI:10.1016/j. semnephrol.2014.02.005

12. Белик С. Н. Молекулы средней массы в определении безопасности мяса и шпика свиней, выращенных с использованием антибактериальных препаратов / С. Н. Белик, Т. С. Колмакова, А. Ф. Степаненко // Мед. вестн. Юга России. - 2014. - № 3. C. 70-73.

13. Gerasymchuk M. R. Place of endogenous intoxication at an early stage of development of the critical states of various etiologies / M. R. Gerasymchuk, I. P. Klishch, N. Yu. Varnava // Inter-Medical Journal. 2015. - No. 3 (9). - P. 21-24.

14. Про затвердження Порядку проведення клінічних випробувань лікарських засобів та експертизи матеріалів клінічних випробувань і Типового положення про комісії з питань етики : Закон Міністерства здоров'я України від 23 вересня 2009 р. № 690 [Електронний ресурс]. - Режим доступу : https:// zakon.rada.gov.ua/laws/show/z1010-09\#Text.

15. Николайчик В. В. "Средние молекулы”-образование и способы определения / В. В. Николайчик, В. В. Кирковский, В. М. Маин // Лаб. дело. - 1989. № 8. - C. 31-33. 
16. Габриэлян Н. И. Скрининговый метод определения средних молекул в биологических жидкостях : метод. рек. / Н. И. Габриэлян, Э. Р. Левицкий, А. А. Дмитриев. - М., 1985.- 22 с.

17. Лапач С. Н. Статистические методы в медикобиологических исследованиях с использованием Excel / С. Н. Лапач, А. В. Чубенко, П. Н. Бабич. - К. : Морион, 2000. - 320 c.

18. Шитов А. Ю. Молекулы средней массы как показатель "гипербарической интоксикации" у водолазов / А. Ю. Шитов // Альм. клинической медицины. 2013. - № 28. - С. 48-52.

19. Особенности развития эндогенной интоксикации при экспериментальной обструкции мочевыво- дящих путей / М. А. Акименко, Т. С. Колмакова, О. С. Оксенюк [и др.] // Вестн. Росс. ун-та дружбы народов. Серия "Медицина". - 2019. - 23, № 3. С. 297-307.

20. Волотовська Н. В. Особливості гепаторенальної реакції на тлі експериментального ішемічно-реперфузійного синдрому / Н. В. Волотовська, А. А. Гудима // Вісн. проблем біології і медицини. - 2020. Вип. 2 (156). - С. 86-91.

21. Динаміка концентрації молекул середньої маси в пацієнтів із тяжкою поєднаною торакальною травмою в гострому періоді травматичної хвороби / М. А. Ступницький, В. І. Жуков, Т. В. Горбач [та ін.] // Травма. - 2014. - № 4. - С. 46-50.

\section{REFERENCES}

1. Anaskin, S.G., Vlasova, T.I., Shevalaev, G.A., Vlasova, V.P., Potyanova, I.V., Suvorova, L.A., \& Zelentsov P.V. (2012). Znacheniye membranostabiliziruyushchey sposobnosti antioksidantov $\mathrm{v}$ ikh detoksikatsionnom effekte [The value of membrane stabilizing ability of antioxidants in their detoxifying effect]. Sovremennye problemy nauki i obrazovaniya - Modern Problems of Science and Education, 6. Retrieved from: http:// www.science-education.ru/ru/article/view?id=7372 [in Russian]

2. Ruiz-Meana, M., \& García-Dorado, D. (2009). Pathophysiology of ischemia-reperfusion injury: New therapeutic options for acute myocardial infarction. Revista Espanola de Cardiologia, 62 (2), 199-209.

3. Wu, M.Y., Yiang, G.T., Liao, W.T., Tsai, A.P., Cheng, Y.L., Cheng, P.W., Li, C.Y., \& Li C.J. (2018). Current mechanistic concepts in ischemia and reperfusion injury. Cellular Physiology and Biochemistry, 46, 16501667. DOI: $10.1159 / 000489241$

4. Volotovska, N.V., Nhokwara, T.C., \& Zhulkevych, I.V. (2019). Changes in the glutathione systems activity of internal organs in the first hours of experimental limb ischemia-reperfusion syndrome, combined with blood loss and mechanical injury. Zdobutky klinich. i eksperym. medytsyny - Achievements of Clinical and Experiment. Medicine, 1, 23-27.

5. Ore, A., \& Akinloye, O.A. (2019). Oxidative stress and antioxydant biomarkers in clinical and experimental models of non-alcoholic fatty liver disease. Medicina, 55 (2), 26. DOI: 10.3390/medicina55020026.

6. Nlandu, Y., Padden, M., Seidowsky, A., Hamaz, S., Vilaine, É., Cheddani, L., Essig, M., \& Massy, Z.A. (2019). Middle-molecule uremic toxins: A renewed interest. $\mathrm{Ne}-$ phrologie \& Therapeutique, 15 (2), 82-90. DOI: 10.1016/j. nephro.2018.09.003.

7. Pianta, T.J., Succar, L., Davidson, T., Buckley N.A., \& Endre Z.H. (2017). Monitoring treatment of acute kidney injury with damage biomarkers. Toxicology Letters, 268, 63-70. DOI: 10.1016/j.toxlet.2017.01.001.

8. Wasung, M.E., Chawla, L.S., \& Madero M. (2015). Biomarkers of renal function, which and when? Clinica Chimica Acta, 438, 350-357. DOI:10.1016/j.cca.2014. 08.039 .

9. Yang, H.T., Yim, H., Cho, Y.S., Kym, D., Hur J., Kim J.H., Chun W., \& Kim H.S. (2014). Assessment of biochemical markers in the early post-burn period for predicting acute kidney injury and mortality in patients with major burn injury: comparison of serum creatinine, serum cystatin- $C$, plasma and urine neutrophil gelatinaseassociated lipocalin. Critical Care, 18 (4), R151, 12. DOI:10.1186/cc13989.

10. Waring, W.S., \& Moonie A. (2011). Earlier recognition of nephrotoxicity using novel biomarkers of acute kidney injury. Clinical Toxycology Testing, 2011, 49 (8), 720-728. DOI:10.3109/15563650.2011.615319.

11. Chmielewski, M., Cohen, G., Wiecek, A., \& Jesús, C.J. (2014). The peptidic middle molecules: is molecular weight doing the trick? Seminars in Nephrology, 34 (2), 118-134. DOI:10.1016/j.semnephrol.2014.02.005.

12. Belik, S.N.. Kolmakova, T.S., \& Stepanenko, A.F. (2014). Molekuly sredney massy $v$ opredelenii bezopasnosti myasa i shpika sviney vyrashchennykh $\mathrm{s}$ ispolzovaniyem antibakterialnykh preparatov [Molecules of middle weight in determining the safety of meat and lard of pigs raised with the use of antibacterial drugs]. Meditsinskiy vestnik Yuga Rossii - Medical Bulletin of the South of Russia, 3, 70-73 [in Russian].

13. Gerasymchuk, M.R., Klishch, I.P., \& Varnava, N.Yu. (2015). Place of endogenous intoxication at an early stage of development of the critical states of various etiologies. Inter-Medical, 3 (9), 21-24.

14. Pro zatverdzennia Poriadku provedennia klinichnykh vyprobuvan likarskykh zasobiv ta ekspertyzy materialiv klinichnykh vyprobuvan: Zakon Ukrainy Ministerstva zdorovia Ukrainy vid 23 veresnia 2009 r. № 690 [On approval of the Procedure for conducting clinical trials of medicinal products and examination of clinical trial materials and the Standard Regulations on Ethics Commissions: Law of the Ministry of Health of Ukraine of September 23, 2009 No. 690: Law of the Ministry of Health of Ukraine No. 690]. Retrieved from: https://zakon. rada.gov.ua/laws/show/z1010-09\#Text [in Ukrainian].

15. Nikolaychik, V.V., Kirkovskiy, V.V., \& Main, V.M. (1989). Sredniye molekuly - obrazovaniye i sposoby opredeleniya [Medium molecules - Formation and methods of determination]. Laboratornoye delo-Laboratory Work, 8, 31-33 [in Russian].

16. Gabrielyan, N.I., Levitskiy, E.R., \& Dmitriyev, A.A. (1985). Skrinigovyy metod opredeleniya srednikh molekul v biologicheskikh zhidkostyakh: Metodicheskiye reko- 
mendatsii [Screening method for the determination of medium molecules in biological fluids: Guidelines]. Moscow [in Russian].

17. Lapach, S.N., Chubenko, A.V., \& Babich, P.N. (2000). Statisticheskiye metody v mediko-biologicheskikh issledovaniyakh s ispolzovaniyem Excel [Statistical methods in biomedical research using Excel]. Kyiv: Morion [in Russian].

18. Shitov, A.Yu. (2013). Molekuly sredney massy kak pokazatel "giperbaricheskoy intoksikatsii" u vodolazov [Molecules of middle mass as an imdicator of diver's "hyperbaric intoxication"]. Almanakh klinicheskoy meditsiny - Almanac of Clinical Medicine, 28, 48-52 [in Russian].

19. Akimenko, M.A., Kolmakova, T.S., Oksenyuk, O.S., Kalmykova Yu.A., Smirnova, O.B. \& (2019). Osobennosti razvitiya endogennoy intoksikatsii pri eksperimentalnoy obstruktsii mochevyvodyashchikh putey [Features of development of endogenous intoxication at experimental obstruction of urinary tracts]. Vestnik RUDN - RUDN Journal of Medicine, 23 (3), 297-307 [in Russian].

20. Volotovska, N.V., \& Hudyma, A.A. (2020). Osoblyvosti hepatorenalnoi reaktsii na tli eksperymentalnoho ishemichno-reperfuziinoho syndromu [Features of hepatorenal reaction on the background of experimental ischemic-reperfusion syndrome]. Visnyk problem biolohii i medytsyny - Bulletin of Problems of Biology and Medicine, 2 (156), 86-91 [in Ukrainian].

21. Stupnytskyi, M.A., Zhukov, V.I., Horbach, T.V., Pavlenko, A.Yu., \& Biletskyi, O.V. (2014). Dynamika kontsentratsii molekul serednoi masy $\mathrm{v}$ patsiientiv iz tiiazhkoiu poiednanoiu torakalnoiu travmoiu $v$ hostromu periodi travmatychnoi khvoroby [Dynamics of concentration of molecules of average weight at patients with a severe combined thoracic trauma in the acute period of a traumatic illness]. Travma - Trauma, 4, 46-50 [in Ukrainian].

\section{ОСОБЕННОСТИ ДИНАМИКИ МОЛЕКУЛ СРЕДНЕЙ МАССЫ НА ФОНЕ МОДИФИКАЦИЙ ЭКСПЕРИМЕНТАЛЬНОГО СИНДРОМА ИШЕМИИ-РЕПЕРФУЗИИ КОНЕЧНОСТИ}

\section{Резюме}

Вступление. Прогностическая роль показателей эндогенной интоксикации на фроне синдрома ишемииреперфузии (СИР) конечности изучена недостаточно, несмотря на значимость этой проблемы в условиях современных боевых действий.

Цель исследования - выяснить особенности изменения концентрации молекул средней массы в сыворотке крови на фроне экспериментального синдрома ишемии-реперфузии конечности.

Методы исследования. После экспериментального моделирования синдрома ишемии-реперфузии особенности эндогенной интоксикации изучали в 260 белых половозрелых крыс-самцов (в возрасте 5-5,5 месяца), которые были разделены на группы: контрольная (n=10); ЭГ1 - моделирование изолированного СИР конечности; ЭГ2 - моделирование изолированной объемной кровопотери; ЭГЗ - сочетание СИР конечности и кровопотери; ЭГ4 - моделирование изолированной механической травмы бедра; ЭГ5 сочетание СИР конечности и механической травмы. В сыворотке крови после завершения эксперимента определяли концентрацию молекул средней массы (МСМ). Количественные показатели обрабатывали статистически.

Результаты и обсуждение. Каждое экспериментальное вмешательство привело к повышению концентрации $\mathrm{MCM}_{254}$ и $\mathrm{MCM}_{280}$. Особенностью является то, что во все исследуемые периоды уровень МСМ был самым высоким на фроне СИР, комбинированного с кровопотерей, что свидетельствует о потенцировании тяжести интоксикации в посттравматический период. Так, в ЭГЗ такая комбинация патогенных фракторов стала причиной возрастания уровня MCM $_{254}$ : на 1-е, 3-е, 7-е и 14-е сутки после нанесения травмы исследуемый показатель превысил данные контрольной группы в 3, 7, 4,2, 3,2 и 2,8 раза соответственно, тогда как концентрация MCM $_{280}$ через 1 ч после вмешательства была больше, чем в контрольной группе, на 53,5%. На 1-е, 3-е, 7-е и 14-е сутки показатель был еще выше - в 3,4, 4, 3,4 и 3 раза соответственно.

Выводы. Каждое из экспериментальных вмешательств привело к нарушению детоксикационно-выделительной фуункци организма, что проявилось увеличением концентрации молекул средней массы. При этом применение кровоостанавливающего жгута, которое изначально должно оказывать лечебный эфрфект, вероятно, имело и патогенное влияние, что необходимо учитывать при проведении лечебных действий таким пострадавшим.

КЛЮЧЕВЫЕ СЛОВА: молекулы средней массы; эндогенная интоксикация; ишемия-реперфузия; травма; кровопотеря; эксперимент. 


\section{PECULIARITIES OF MEDIUM MOLECULES DYNAMICS ON THE BACKGROUND OF MODIFICATIONS OF EXPERIMENTAL ISCHEMIC REPERFUSION SYNDROME OF THE LIMBS}

\section{Summary}

Introduction. The prognostic role of indicators of endogenous intoxication on the background of limb ischemicreperfusion syndrome is insufficiently studied, despite the importance of this problem in modern hostilities.

The aim of the study - to investigate the peculiarities of the change in the concentration of middle mass molecules in the blood serum on the background of the experimental limb ischemic-reperfusion syndrome.

Research Methods. After experimental modeling of IRS, the features of endogenous intoxication were studied in 260 white adult male rats (5-5.5 months) which were divided into 6 groups: control, EG1 (modeling of isolated limb IRS), EG2 - modeling of isolated volumetric blood loss, EG3 - combination of limb IRS with blood loss, EG4 modeling of isolated mechanical injury of the thigh, EG5 - combination of limb IRS and mechanical injury. After experiment completion middle mass molecules were determined in the blood serum. Quantitative indicators were processed statistically.

Results and Discussion. It was found that each experimental intervention led to an increase in $M M_{254}$ and $M M M_{280^{\circ}}$ The peculiarity was that in all studied periods the level of MMM was the highest on the background of IRS combined with blood loss, which indicated the potentiation of the intoxication severity in the post-traumatic period. Thus, in EG3, the combination of IRS with blood loss led to the following increase of $M M_{254}: 1,3,7$ and 14 days after injury the figure of MMM exceeded the CG data by 3.7, 4.2, 3.2 and 2.8 times respectively, while the concentration of $M M M_{280}$ in $1 \mathrm{~h}$ after the intervention was higher than the CG data by $53.5 \%$. Also, at $1^{\text {st }}, 3^{\text {rd }}, 7^{\text {th }}$ and $14^{\text {th }}$ days - the figure was even higher - by 3.4 times, 4 times, 3.4 and 3 times respectively.

Conclusions. Thus, each of the experimental interventions led to a violation of the body detoxification and excretory function, which manifesteded itself in an increase of the MMM level. In this case, the use of a tourniquet, which should initially make a therapeutic effect had a pathogenic influences, which should be adopted when carrying out therapeutic actions for such victims.

KEY WORDS: middle mass molecules; endogenous intoxication; ischemia-reperfusion; injury; blood loss; experiment.

Отримано 10.11.20

Адреса для листування: Н. В. Волотовська, Тернопільський національний медичний університет імені І. Я. Горбачевського моз України, майдан Волі, 1, Тернопіль, 46001, Україна, e-mail: volotovskanv@tdmu.edu.ua. 